6-3-2016

\title{
In the Land of the Mountain Gods: Ethnotrauma and Exile among the Apaches of the American Southwest
}

M. Grace Hunt Watkinson

Arizona State University at the Tempe Campus

Follow this and additional works at: https://digitalcommons.usf.edu/gsp

\section{Recommended Citation}

Hunt Watkinson, M. Grace (2016) "In the Land of the Mountain Gods: Ethnotrauma and Exile among the Apaches of the American Southwest," Genocide Studies and Prevention: An International Journal: Vol. 10: Iss. 1: 30-43.

DOI:

http://dx.doi.org/10.5038/1911-9933.10.1.1279

Available at: https://digitalcommons.usf.edu/gsp/vol10/iss1/6

This is brought to you for free and open access by the Open Access Journals at Digital Commons @ University of South Florida. It has been accepted for inclusion in Genocide Studies and Prevention: An International Journal by an authorized editor of Digital Commons @ University of South Florida. For more information, please contact digitalcommons@usf.edu. 


\title{
In the Land of the Mountain Gods: Ethnotrauma and Exile Among the Apaches of the American Southwest
}

\author{
M. Grace Hunt Watkinson \\ Arizona State University \\ Tempe, AZ, USA
}

\begin{abstract}
In the mid to late nineteenth century, two Indigenous groups of New Mexico territory, the Mescalero and the Chiricahua Apaches, faced violence, imprisonment, and exile. During a century of settler influx, territorial changeovers, vigilante violence, and Indian removal, these two cousin tribes withstood an experience beyond individual pain best described as ethnotrauma. Rooted in racial persecution and mass violence, this ethnotrauma possessed layers of traumatic reaction that not only revolved around their ethnicity, but around their relationship with their home lands as well. Disconnected from the ritual resources and sacred geographies that made up every day Apache living, both groups faced a profound and uphill struggle to maintain their community and very identity in the wake of immense and collective psychological distress. This essay emphasizes the role that geography plays in both the immediate impact of exile trauma and in the healing possibilities that this sacred connection to place has to offer Indigenous communities, even in the midst of exile.
\end{abstract}

Keywords: trauma, indigenous, race, violence, imprisonment, exile, place, geography

"Listen my child, listen carefully," Dilth-cleyhen's mother had said. "Listen, and maybe you can hear the songs, the drumming - but you must listen. It is very faint. It is the sound of our sacred ones, the Mountain Gods."1

\section{Introduction}

During an 1861 raid on Apache Chief Geronimo's camp, Mexicans captured and sold into slavery a young seventeen-year-old Native named Francesca, known to her Chiricahua Apache brethren as Id-is-tah-nah. Francesca's captors sold her, along with three other Apache girls, to a maguey planter in Sonora, Mexico. Five years later, under the facade of attending a local religious event at a nearby church, Francesca and her friends escaped, walking north through mountains and deserts in order to reach their homeland. They slept during the day to evade capture, surviving largely on tunas, the fruit of the prickly pear cactus. One night in the mountains, a jaguar attacked the group, nearly killing Francesca in the process. Though the girls managed to kill the jaguar and treat Francesca's wounds as best they could, this near-death experience seriously injured Francesca and postponed further travel of the group for a month. Eventually, the girls made their way back to their home in Arizona, but Francesca carried the scars of her horrific journey on her face and hands for the rest of her life. She often hid marks left by the attack from even her own people, but the rest of the Chiricahua Apaches viewed her scars as a sign of her drive, tenacity, and devotion to home. This experience with captivity, however, would not be Francesca's last. ${ }^{2}$

Francesca's story, though unique in its inclusion of a jaguar attack, represents only one of several oral histories within Apache history telling of escape and the journey home. The Apache peoples, though largely "nomadic" and mobile, have always held an intimate connection to the landscape of the Southwest and their homeland. This distinctive spiritual connection, passed down through sacred stories and tangled within their cultural, economic, and social institutions, remains an integral part of Apache identity.

During the mid-nineteenth century, even as their lands faced increasing instability and constriction with the onset of American settlement, Apache tribes such as the Chiricahua and the Mescalero retreated further into the heartlands of their territory. With the United States military's removal of hundreds of Mescalero people to Bosque Redondo reservation in New Mexico Territory in 1861, and decades later, the Chiricahua relocation to a prison camp in Saint Augustine, Florida,

\footnotetext{
${ }^{1}$ Ruth McDonald Boyer and Narcissus Duffy Gayton, Apache Mothers and Daughters: Four Generations of a Family (Norman: University of Oklahoma Press, 1992), 5.

${ }^{2}$ Sherry Robinson, Apache Voices: Their Stories of Survival as Told to Eve Ball (Albuquerque: University of New Mexico Press, 2000), 27-29.
} 
in 1886, this exile created a severe rift within their ethnic identity as the federal government sent them far from home. ${ }^{3}$ Due to their intimate and visceral connection to their landscape, the forced relocation produced a unique layer of ethnotrauma which pushed these two groups into reactive identities of survival in an exiled captivity.

\section{Indigenous Ethnotrauma}

This essay establishes the term ethnotrauma to describe the layered experience of trauma within Indigenous communities, emphasizing the importance of sacred geography among Indigenous peoples as a particularly profound factor in this collective trauma. Ethnotrauma exists as an expanded version of the wounding of soul felt by victims of natural disaster, violence, and intense psychological duress, but beyond typical trauma, the experience of ethnotrauma lurks within racial, religious or culturally-based persecution and encapsulates multiple, building layers. The foundation of this ethnotrauma lies first within the self, as the individual psyche processes traumatic events. Group persecution then adds to this experience, lasting psychological effects beyond the individual experience of post-traumatic stress syndrome. ${ }^{4}$ Within communally rooted cultures, particularly Indigenous peoples, this ethnotrauma develops out of an attack on not merely a person or people but on the cultural identity of the group at large.

Yet for the Mescalero and Chiricahua peoples of the nineteenth century American Southwest, their experience contained an additional layer of trauma, based within their forced uprooting from their homeland. Their ultimate exile and imprisonment after decades of war and conflict pushed both Apache groups into a liminal disconnect from their cultural landscape and a brokenness that could only be mended through a processing of pain within ritual and community. This cultural genocide committed by both state and citizen impacted on multiple generations in both captivity and beyond.

Though the application of the term "genocide" has long caused scholarly controversy within Native American academic studies, genocide, much like the term ethnotrauma, consists of a variety of layers situated along a spectrum. Ethnotrauma in the case of the Mescalero and Chiricahua Apaches exists largely as a reaction to this cultural genocide, or ethnocide, a term first theorized in Rafael Lemkin's Axis Rule in Occupied Europe. ${ }^{5}$ More recently, scholars Benjamin Madley, Patrick Wolfe, Alex Alvarez, and others have expanded the concept of both cultural and physical genocide into a broader term of nuanced proportions, shifting away from its legalistic definition coined in the aftermath of World War II.

Benjamin Madley argues for a closer reviewing process of the individual treatments of bands and Native units, rather than the broad and often inaccurate application of a victim and perpetrator binary to post-contact Indian history. ${ }^{6}$ Meanwhile, Patrick Wolfe moves genocide into a different and far broader conceptualization with his exploration of settler colonialism. Wolfe argues that the process of settler colonialism remains, at its heart, a process of developing patterns of genocidal intent through the establishment of colonial infrastructures and institutions. ${ }^{7}$ Alex Alverez further expands on Wolfe's theories when he refers to this process of ethnic inclusion via these colonial systems at the cost of genocidal exclusion as "inherently exterminatory." ${ }^{8}$

As one examines the removal of both these Apache groups, and particularly the lead-up to their exile, one cannot help but note these patterns, noted more broadly by Madley and Alvarez, of

\footnotetext{
${ }^{3}$ For more information on the Apache removal periods, see C.L Sonnichsen, The Mescalero Apaches (Norman: University of Oklahoma Press, 1958); Edwin R. Sweeney, From Cochise to Geronimo: The Chiricahua Apaches, 1874-1886 (Norman: University of Oklahoma Press, 2010).

${ }^{4}$ Ameena T. Ahmed, Selina A. Mohammed, and David R. Williams, "Racial Discrimination and Health: Pathways and Evidence," Indian Journal of Medical Research 126, no. 4 (2007), 318.

${ }^{5}$ Raphael Lemkin, Axis Rule in Occupied Europe: Laws of Occupation - Analysis of Government - Proposals for Redress (Washington, D.C.: Carnegie Endowment for International Peace, 1944), 79- 95.

${ }^{6}$ Benjamin Madley, "Reexamining the American Genocide Debate: Meaning, Historiography, and New Methods," The American Historical Review 120, no. 1 (2015), 98-139.

${ }^{7}$ Patrick Wolfe, "Settler Colonialism and the Elimination of the Native," Journal of Genocide Research 8, no. 4 (2006), 387-409.

${ }^{8}$ Alex Alvarez, Native America and the Question of Genocide (Lanham: Rowman \& Littlefield, 2014), 57.
} 
ethnically-driven persecution. Often violent, these encounters were perpetrated by both the nonIndigenous public as well as federal and territorial actors and institutions. Yet physical violence, as explored later in this article, only accounts for half of the Apache suffering. Once imprisoned, the cultural genocide caused by this experience of enclosure would create a lasting wound within the Apache collective consciousness. Perhaps the most clarifying conceptualization of the specific Apache experience with genocide, however, lies in the Apache people's own words on the topic. When twentieth century historian and author Eve Ball interviewed Mescalero Apache Frederick Peso about his people's possible experience with genocide at Bosque Redondo, he stated eloquently, "I am sure that that was the intention. The surest way to kill a race is to kill its religion and its ideals...That is to kill the soul of a people. And when the spirit is killed, what remains?"'

\section{Cycles of Violence and Trauma within a Sacred Geography}

Both the Mescalero and Chiricahua Apaches faced vigilante and military violence in the American Southwest through numerous decades at the hands of the Mexican and later American military, culminating in forced removal, criminalization, and imprisonment. While the Mescalero Apaches faced direct physical destruction through forced incarceration for several years at the inhospitable Bosque Redondo reservation in 1860s New Mexico, the Chiricahua Apaches faced a more indirect path to ethnotrauma through decades of harsh separation from their homeland as prisoners of war in the east. Additionally, these groups faced a long, spiritual pain far more devastating to them than their physical persecution, as the bonds between place and existence fractured during the exile and incarceration process. Through their research, trauma scholars Dominick LaCapra, Michael Rothberg, and Cathy Caruth have created a more complex understanding of this multigenerational trauma that groups such as the Apaches faced as ethnic collectives. ${ }^{10}$

Apache peoples of the nineteenth century dealt with cyclical violence on an everyday basis. Both the Mescalero and Chiricahua tribes were embroiled during this period in the Indian and Mexican slave trade, a practice more akin to indentured servitude than to East Coast chattel slavery but no less traumatic for its victims. ${ }^{11}$ Facing increasing hostilities from white settlers pouring in from the East and in the aftermath of the Apache wars with the US military, these two Apache groups contended with a fracturing of their cultural selves and an agonizing sense of limbo as they struggled to maintain their communal systems in a land far away from the drumming of the mountain gahns. ${ }^{12}$

Due to their semi-mobile nature, the Mescalero and Chiricahua's traditional territory encompassed a wide swath of lands. Stretching from the Sierra Blanca in southeastern New Mexico all the way into the Texas panhandle, the Apaches inhabited the ranges of the Guadalupe as well as the Davis mountains. Although culturally rooted to the arid highlands and peaked ranges of the region, the Apaches also lived and hunted among the deserts and brush lands with the changing seasons. ${ }^{13}$ Though raiding featured heavily within the Apache economy, particularly during the seventeenth and eighteenth centuries, Apache well-being and material culture still revolved entirely around the seasonality of nature. Yet regardless of this mobility, the Apaches, down to individual bands and family units, always returned to their sacred spaces, rooted in spiritual and oral history, whether in the mountains, among the rivers, or deserts and plains. The Spaniards referred to this vast expanse of tribal territory as Apacheria. ${ }^{14}$

\footnotetext{
${ }^{9}$ Eve Ball, Indeh: An Apache Odyssey (Norman: University of Oklahoma Press, 1980), 81.

${ }^{10}$ For more information on the concept of multigenerational trauma, see Dominick LaCapra, Writing History, Writing Trauma (Baltimore: John Hopkins University Press, 2001); Michael Rothberg, Multidirectional Memory: Remembering the Holocaust in the Age of Decolonization (Stanford: Stanford University Press, 2009); Cathy Caruth, ed. Trauma: Explorations in Memory (Baltimore: John Hopkins Press, 1995).

${ }^{11}$ James F. Brooks, Captives and Cousins: Slavery, Kinship, and Community in the Southwest Borderland (Durham: University of North Carolina Press, 2011).

$12 *$ *ahns or Ga'ans are ancestral spirits linked with Apache creation stories who dwell within the mountains of the Apache homeland, protecting Apache peoples from harm.

${ }^{13}$ Sonnichsen, The Mescalero Apaches, 4.

${ }^{14}$ Daniel L. Thrapp, The Conquest of Apacheria (Norman: University of Oklahoma Press, 1967).
} 
In 1539 when the Spaniards first pierced the landscape with exploration, Apache groups dotted this new empire's northern borderlands. Western Apaches thrived in the countryside along the Rio Grande, and Eastern Apache groups stretched as far northeast as Kansas. Apache bands at the time consisted of those still found today, such as the Mescaleros, Jicarillas, and Lipans, as well as some lesser known groups such as the Carlanas, Palomas, Apaches del Perillo, Faraones, and Natages. All of these groups, however, periodically merged and separated based on the leadership and resources available, and in light of alterations to population resulting from violence and disease. ${ }^{15}$

Regardless of the size and scope of their territory as well as their semi-nomadic lifestyles, both the Chiricahua and Mescalero Apaches have always held a distinctive connection to their territory. In November 1951, Percy Big Mouth, the last living Apache scout under Geronimo and a child prisoner with many Mescalero Apaches at Bosque Redondo, declared in reference to Apacheria during one interview with Eve Ball, "It has always been our country." 16 Similarly, recalling the Chiricahua homeland, Geronimo once stated,

For each tribe of men Usen created He also made a home. In the land for any particular tribe He placed whatever would be best for the welfare of that tribe. When Usen created the Apaches. He also gave them their homes in the West. He gave them such grain, fruits, and game as they needed to eat...He gave them a pleasant climate and all they needed for clothing and shelter was at hand. Thus it was in the beginning: the Apaches and their homes each created for the other by Usen himself. When they are taken from these homes they sicken and die. ${ }^{17}$

The stereotype of the constantly prowling, disconnected Apache, however, fed into public notions of Apache homelessness with American annexation of the region from Mexico in 1848. Espousing an entirely Western view of sedentary living as a pinnacle of civilization, American settlers perceived Apaches as rogue groups lacking a definitive home, but the Apaches always maintained a deep understanding of their territorial bounds, with their demarcations centered on the sacred places of modern day New Mexico, Arizona, and northern Mexico. ${ }^{18}$

Philosopher Edward S. Casey has long argued that place, centuries ago, lost its importance among time and space as philosophers sought to analyze who we are as both individuals and as collectives of individuals. In his treatment of place, Casey looks at the temporal and memorial or historical factors at work in moving the critical nature of geography beyond mere positioning and into a realm far more meaningful for the individuals or peoples under analysis. Casey argues further that bodily movement established in many cases a sort of civil disobedience in regard to place. ${ }^{19}$ In the same way that the increasing motion of warring Apaches alarmed and incited warfare with the American military, so too did the continued motion and raiding practices constitute spatial ownership and agency for the Apache peoples.

Harry Basehart, an ethnographer of the Apaches, described the movements of the Mescalero Apaches in his study, arguing that while some leaders followed patterns, moving camps small distances in the short term and to particular mountains at specific times of year, other leaders and their bands moved much more sporadically, reflecting the variation in mobility among individual groups. One Mescalero Apache whom Basehart interviewed referred to this region not as the territory of his people, but as "our country." ${ }^{20}$ The American government's vast misunderstanding

\footnotetext{
${ }^{15}$ Sonnichsen, The Mescalero Apaches, 32.

${ }^{16}$ Eve Ball, “Big Mouth,” n.p., Eve Ball Papers, November, 1951, Manuscript Collection 3096, L. Tom Perry Collection, 20th and 21st century Western and Mormon Americana, Harold B. Lee Library Provo, U.S., Box 3, Folder 22.

${ }^{17}$ Angie Debo, A History of the Indians of the United States (Norman: University of Oklahoma Press, 1970), 3.

${ }^{18}$ William M. Clemens, Imagining Geronimo: An Apache Icon in Popular Culture (Albuquerque: University of New Mexico Press, 2013), 69

${ }^{19}$ Azucena Cruz-Pierre, Donald A. Landes, and Contributors, Exploring the Work Of Edward S. Casey: Giving Voice to Place, Memory, and Imagination (London: Bloomsbury, 2013), 37-56.

${ }^{20}$ Harry W. Basehart, Apache Indians XII; Mescalero Apache Subsistence Patterns and Socio-Political Organization (New York: Garland Publishing Inc., 1974), 105-110.
} 
Hunt Watkinson

of symbiotic Indigenous land relations, however, would ultimately undermine Apache claims to their homeland in the aftermath of both the Mescalero and Chiricahua wars.

\section{The Apache War Period}

For the Mescalero Apaches, their rift from their homeland came during the early 1860s. By the start of the Civil War, the Mescalero people shared an unstable relationship with the still new American government in the region. While some chiefs continued leading violent raids, other chiefs such as Cadette negotiated with local Indian agents and attempted less mobile settlements and agricultural practices. Working from broad and simplistic assumptions that Apaches were innately violent and war mongering, however, the New Mexico territorial government, with the backing of the federal government in Washington, gave Union General James Carleton unbridled control over the Mescalero people's future. With the Civil War raging in the east, the territorial government sought to placate the various tribes in the region who had begun raiding anew in the chaos of a failed Confederate invasion. Concise and brutal, General Carleton's military action targeted not only fighting Mescalero Apache warriors of the tribe but women and children as well. ${ }^{21}$ Begun during the summer of 1862, the campaign lasted a mere five months. Eventually, this campaign would culminate in the forced incarceration of many Mescalero Apaches at a bleak and isolated location near Fort Sumner in eastern New Mexico territory, known as Bosque Redondo. ${ }^{22}$

Carleton ordered the application of total warfare tactics that typified methods practiced against Native Americans of the time period. Oral histories from survivors, and the children and grandchildren of survivors, still attest to the painful experiences of watching fathers die as they fought back soldiers while their wives and children scaled canyon walls to evade capture. Big Mouth, a Mescalero Apache who spent his childhood at Fort Sumner, spoke of his family's traumatic recollections to Eve Ball. Big Mouth described the deaths of both his father and other warriors early on during the campaign as they fought to protect fleeing women and children from capture by American soldiers. ${ }^{23}$ Afterward, Big Mouth and his surviving family members made the long walk with other captured Mescalero people to Fort Sumner and the Bosque. The journey into exile totaled around 137 miles with few rations. ${ }^{24}$ Big Mouth stated in reference to his people's experience:

It was a terrible journey, for the women were attacked by the soldiers, and no officer did anything to prevent it. Mescalero women were chaste and very modest. The men could not look at each other; they could do nothing to protect the women and were ashamed. They wished they had chosen death in the land given them by Ussen, but it was too late; they were now captives. ${ }^{25}$

Stories of the "Long Walk," such as Big Mouth's, do not merely contain tales of bodily pain but also reflect upon the complex emotional shame and sorrow of people experiencing tremendous racial persecution and an uncertain incarceration in foreign lands. The stories that trickled down into the oral histories of the Mescalero people all seem to center upon this psychological wounding indelibly stamped into Apache memory. Dominick LaCapra argues that victims of trauma face a shattering of identity and a rupture in memory, leaving them at a crossroads to recreate the self. ${ }^{26}$ The Mescalero Apaches, after suffering through the hardships of total warfare, faced a brokenness caused by violence and racial persecution that led them to reevaluate their communal identity upon reaching Bosque Redondo. Yet beyond this fracturing of self and culture, the Mescalero people also contended with a rupture of identity and place. This intertwined Indigenous identity, characterized

\footnotetext{
${ }^{21}$ Sonnichsen, The Mescalero Apaches, 99-120.

${ }^{22}$ William A. Keleher, Turmoil in New Mexico: 1846-1848 (Albuquerque: University of New Mexico Press, 1952$), 29$.

${ }^{23}$ Ball, Indeh, 121.

${ }^{24}$ John C. Cremony. Life Among the Apaches (San Francisco: A. Roman \& Company, 1868), 201.

${ }^{25}$ Ball, Indeh, 121.

${ }^{26}$ Dominick LaCapra, History and Memory after Auschwitz (Ithaca, NY: Cornell University Press, 1998), 9.
} 
by strong social, familial, and cultural ties to the broader community and encompassing a variety of traditional subsistence practices, then had to be reconstructed on a new reservation in the wake of physical and emotional destruction.

During those first fateful months at the Bosque, while the Apaches worked diligently creating a new communal home, the population began to feel the shock of being removed from their traditional homeland to such a desolate landscape. Placed among the sagebrush and sparse cottonwood trees of the barren New Mexican East, these Apache bands faced a monumental change of place when compared to their previous wooded mountain ranges in the territory's southern borderlands. ${ }^{27}$ Ripped away from the places that defined them and still reeling from the horrors of war, the Mescalero carefully followed the military's guidance in regard to farming, housing structures, and political organization while on the reservation. ${ }^{28}$

Ultimately, after the population swelled to over 4,000 with the addition to the reservation of captured Navajo Indians, these Native prisoners faced increasingly dire circumstances with famine, blight, outside Indian attacks from various Plains groups, restriction from off-reservation hunting, as well as malnutrition and disease. Finally, on November 3, 1865, under cover of night and the guidance of the elders of the group, all Apaches, then totaling close to 400, disappeared from the Bosque, leaving only nine sick Apaches who within a few days also vanished. ${ }^{29}$ This return home for the Mescalero, much like Francesca's return home to the land of the Chiricahua, did not merely represent a connection to place for the Apaches. Instead, this defiant bid for freedom also symbolized the resonant sense of agency that did not lead the Mescalero into exiled hiding but rather to freedom in the mountain hollows of Apacheria.

For the Chiricahua Apaches, their largest removal came after several decades of intermittent warfare with the Mexicans, settlers, and American troops along the territorial Southwestern borders. During this violent period which occurred in the lead-up to Chiricahua removal in 1886, known as the Apache Wars, various Apache chiefs from Cochise and Victorio to Naiche and Geronimo sought peace on one hand and violence on the other as they attempted to stop white incursion into their territory and provide food and shelter for their peoples. In the early 1870s, the Apache leader Cochise negotiated a possible reservation within his people's homeland. ${ }^{30}$ During these talks, federal agents and military men pushed for Cochise to relocate his warring band to a reservation at Tularosa, around 100 miles away from Canada Alamosa, a place which Cochise's people considered to be the heart of their homeland. Cochise similarly rejected this location as a reservation, stating; "I want to live in these mountains; I do not want to go to Tularosa. That is a long ways off. The flies on those mountains eat out the eyes of the horses. The bad spirits live there. I have drunk of these waters and they have cooled me; I do not want to leave here." ${ }^{31}$ Cochise also questioned the government's role in dictating another people's definition of home, stating: "When I was young I walked all over this country, east and west, and saw no other people than the Apaches. After many summers, I walked again and found another race of people had come to take it. How is it? Why is it that the Apaches wait to die-that they carry their lives on their fingernails?" 32 At this point in Cochise's life, in poor health and over sixty years old, the leader recognized that his choices had increasingly narrowed to keep his remaining followers alive. Regardless, he still attempted to defend his group's place near their mountainous stronghold.

\section{Apache Religion and the Holy Landscape}

The public image of the Apache Indian denotes a marauder on horseback, raiding and roaming across a barren desert landscape among the shrubs and arid lands. This stereotype, however, lies

\footnotetext{
${ }^{27}$ Martin Ball, "Sacred Mountains, Religious Paradigms, and Identity Among the Mescalero Apaches.” Worldviews: Global Religions, Culture, and Ecology 4, no. 3 (2000), 264-282.

${ }^{28}$ Sonnichsen, The Mescalero Apaches, 116.

${ }^{29}$ Ibid., 118-121.

${ }^{30}$ Edwin R. Sweeney, Cochise: Chiricahua Apache Chief (Norman: University of Oklahoma, 1991), 322-339.

${ }^{31}$ Ibid., 339.

${ }^{32}$ Edwin R. Sweeney, ed. Cochise: Firsthand Accounts of the Chiricahua Apache Chief (Norman: University of Oklahoma, 2014), 179 .
} 
far from how the Mescalero and Chiricahua Apaches see themselves in the past and present. ${ }^{33}$ Both of these groups possess a profound association with the mountains that surround their territories. For these peoples on an economic and militaristic level, their mountain ranges represented a seasonal holdout where game remained ample in the face of changing weather and where deep, defensible canyons waited for the Apache people in times of trouble.

For many non-Indigenous settlers of the Southwest, this concept of place attachment seemed difficult to comprehend. Penelope Harvey characterized this strong connection to the environment when examining geographic agency within the worldview of Indigenous Andeans, stating, "In this respect it is important to understand that the personhood of hills and pathways is not a metaphorical extension of human attributes. Personhood is literal." ${ }^{34}$ In the same manner, the Chiricahua as well as Mescalero Apache wars with Spaniards, Mexicans, and Americans over multiple centuries empowered the Apache landscape through these conflicts, all the while intersecting with the agency of the land itself. Knowledge of these formidable desert and mountain spaces provided Apaches, regardless of their racial and class position within various societies and time periods, with pieces of this power. Once removed from their homelands by American forces, however, the power of place fractured in traumatic ways.

One facet of this place attachment lies in Apache theology and spirituality. Protecting Native religious beliefs in the face of forced conversions and socio-political pressures allowed the Mescalero Apaches, like many other tribes of the Southwest, to maintain their spiritual practices throughout the centuries. Much as Ussen, creator of all supernatural power, linked the spirit world with that of his physical creations, abstract religious beliefs merged with everyday life and cultural systems, linking multiple levels to economic institutions within the tribe. Though these beliefs seemed to non-Indigenous individuals from Spain, Mexico, and America as pagan and primitive, Mescalero Apaches lived so enmeshed within their concept of the spiritual world that any attack upon this system became an attack upon their identity as a people. Asa Daklugie, an Apache interviewed by Eve Ball, expressed the absolute importance of understanding Apache religion in reference to their collective identity:

Without at least a little understanding of our religion it is difficult to comprehend what motivates the Apache. My people have never liked to talk about our religion, partly because they anticipate ridicule, but more because it is the only thing we possess of which the whites have not robbed us. Instead of trying to force it upon all whom we contact, as your people seem to be obligated to, we preserve it for ourselves and our children. It is the one thing of which we cannot be deprived... Each morning as the sun first appears on the horizon, the father of the family stands at the door of his tepee, always facing the east, and with eyes and arms uplifted prays to Ussen - not to the sun, but to Ussen. ${ }^{35}$

For Daklugie, this inseparable aspect of Apache identity also represents a remaining bastion of cultural stability. With a history rife with cyclical violence, racial persecution, massacre, and exile, this tangling of spirit and the everyday brought a sense of continuity to the Apaches, even in times of collective trauma, and much of that entanglement continually engaged the resources and geographic anchor points of the Apache world on a religious level.

For the Chiricahua Apaches, though Ussen created the world, the spaces within that world take on a separate meaning in regard to particular events. Berle Kanseah, a Chiricahua tribe member stated in reference to the spiritual power of land, "It's ours, and it's sacred, and it's how we were intended to be, placed here in the Southwest." 36 As the Chiricahua moved down from

\footnotetext{
${ }^{33}$ For more on the long manipulated white-produced image of the Apaches, see Janne Lahti, "Silver Screen Savages: Images of Apaches in Motion Pictures." Journal of Arizona History, 55, no. 1 (2013), 51-79.

${ }^{34}$ Penelope Harvey, "Landscape and Commerce: Creating Contexts for the Exercise of Power," in Contested Landscapes: Movement, Exile, and Place, ed. Barbara Bender and Margot Winer (Oxford: Berg Publishers, 2001), 198.

${ }^{35}$ Ball, Indeh, 56-58.

${ }^{36}$ H. Henrietta Stockel, “Rocks, Waters, and Earth: Chiricahua Apache Spiritual Geography," Journal of the West 46, no. 4 (2007), 12.
} 
the North into their present homeland in southwest Arizona and New Mexico, they applied their own notions of community to the spaces around them. For this Apache group, land and place represented entities with which to develop a separate but equal relationship. This relationship, characterized by mutual sustainability, then became ingrained within their spiritual, economic, and cultural practices. ${ }^{37}$

Martin Ball described Apache belief systems as "a religion of place." 38 The Mescalero Apaches in particular consider the mountains of their Southwestern territory to be holy. In this vast landscape, often the most sacred of spots possessed water, rich biodiversity, or other strategic resources. While the Mescalero Apaches can name multiple sacred mountains, only a few of these mountains are considered "medicine mountains." ${ }^{39}$ Yet Ball does not describe the mountains as possessing what he terms "spiritual ecology" and power because of their abundance of medicinal fauna. ${ }^{40}$ Instead, Ball argues that the mountains produce such fauna because of their own primal inundation with power. Mescalero Apaches that Ball interviewed claimed that often this power can become tangible and tactile as one gets closer to the peaks. One interviewee described to Martin Ball how when Ussen flooded the world in its earliest days, the spirits had no place to go. The mountain peaks, however, still jutted out of the floodwaters. The spirits invaded these peaks and there the gahns, or mountain gods, assumed their present form, giving their power to the landscape. According to tribal leader Paul Ortega, as long as the Mescalero Apaches remained centered within the four sacred mountains which gave the four Crown Dancers life, then the people there would remain protected. ${ }^{41}$

Apache religion does not revolve around solely the largest entities of the natural world. Even the smallest of substances within the landscape can take on tremendous spiritual symbolism and power. Tule pollen, called hoddentin, marks the bodies of Apaches during much of their ceremonial practices. This yellow substance, carefully prepared by medicine men from the cattail plant at a particular point in the flora's lifespan, moves through Apache life and even death. Warriors would carry this symbol of the sun's life-giving power into battle and would use it in prayer at the bedsides of the dying. In combination with frequent prayers, the pollen could also be thrown into the four sacred directions to express gratitude for a good hunt or battle won. In this manner, Apache, earth, life, death, sun and stars remained inextricably linked. ${ }^{42}$

The Mescalero Apache world remains rooted in everyday rituals and constant alignments that connect their people to their past and a greater, more metaphysical "cosmovision," a connection between religion and astronomy. While working with elder Bernard Second on the Mescalero Apache reservation, Claire Farrer observed that puberty ceremony lodges and other constructions aligned with the sun and constellations in a perfectly coordinated pattern, complex and simultaneously riddled with metaphors and symbols. Farrer noted that pre-school-aged Apaches rode their bicycles in an east to west pattern, following the rising and setting of the sun. In addition, she also noted that all Apaches carefully spread salt on their food at meals in a similar motion. Farrer realized that these everyday rituals constantly confirmed the supreme connection still held between Apache, earth, and the cosmos. ${ }^{43}$

Religious rituals of both Apache groups remain a key part of Apache spirituality, reminding practitioners of the past and of place within their everyday lives. Anthropologist Morris Opler noted that when near their birthplaces, individual Apaches will sometimes roll on the ground in the four sacred directions to honor the sanctity of their birthplace. Similarly, a child's first laugh ceremony honors their entry from the spirit world of the ancestors into the physical realm of his or her living family. Other rituals such as the cradle ceremony incorporate native natural elements under the

${ }^{37}$ Ibid., 18 .

${ }^{38}$ Ball, "Sacred Mountains, Religious Paradigms, and Identity among the Mescalero Apache", 264.

${ }^{39}$ Ibid., 267.

${ }^{40}$ Ibid., 268.

${ }^{41}$ Ibid., 267-278.

${ }^{42}$ H. Henrietta Stockel, Salvation through Slavery: Chiricahua Apaches and Priests on the Spanish Colonial Frontier (Albuquerque: University of New Mexico Press, 2008), 16

${ }^{43}$ Claire R. Farrer, Living Life's Circle: Mescalero Apache Cosmovision (Albuquerque: University of New Mexico Press, 1994). 
guidance of the shaman in the construction of an infant's cradle board. ${ }^{44}$ The Apaches also use the act of naming as a way of building meaning into and creating dynamic power relations within their spiritual geography, viewing their history less in terms of when events occurred and more in terms of where events occurred. These names, recorded through generations of oral tradition, establish a method of connecting with the land's "personhood," engaging with geography in a manner that allows for continuity as well as change. ${ }^{45}$

Harry Basehart's ethnographic study of the Mescalero people expands on this concept of an organic relationship with the land, complicating the image of the Apaches' sacred geography. In the 1970s this ethnographer analyzed the multiple place names and the concurrent meanings that these names evoked to the elders he interviewed within this Apache group. The Mescalero referred to their peaks in New Mexico as "the sacred mountains," believing that these spaces did not merely symbolize home but that they also held a spiritual power all their own. Though Basehart interviewed multiple Natives on the place names and importance of local spaces, all seemed to hold Guadalupe Peak in great regard. The elderly noted this peak as "a holy place...people go to that mountain and raise their hand up to the mountain and pray for all the good things: that no sickness will come to them and that the good luck will be with them." ${ }^{46}$ Much like the sacred sites of saintly miracles in Christian beliefs, the Mescalero Apaches invoked stories of their origins and how their world came to be when Basehart asked them about specific locations. Some of these sites held more reverence than others, while other places hearkened back to critical lessons learned by Mescaleros in the past. In one location bison emerged from the earth in the early days of existence. At another location a woman died after improperly cutting down a pinon tree. ${ }^{47}$

Intertwined within the sacred geography and cosmology of the Apaches lies the balance of all power. The Chiricahua believe that in the era before creation by Ussen, only time and power existed. ${ }^{48}$ Ussen represented this power and all the aspects contained within it. Power begot power, and power fought power as dueling entities of pure force battled to overcome the balance of the universe. Once Ussen, power's culmination, created the world, these spiritual powers continued to clash for superiority in the spiritual realm, largely ignoring humankind and their petty affairs. Within this eternal struggle, however, no concept of good or evil existed. Instead these varying concepts of power merely loomed, lacking in any proscribed morality or contrast. Apaches strive to harness these powers within their own lives, yet Apaches also firmly believe that power seeks out human beings to possess it. Additionally, one could refuse power bestowed by these metaphysical spirits since taking on such a tremendous energy also entails grave responsibility to the accepting person. In this manner the earth and the cosmos, comprised of this eternal and sacred power, move through the Apache individual with their own agency and life force. Some Apache people believe that these powers will remain incomplete until harnessed by an individual while other Apaches add more humanistic qualities to this entity, arguing that the power desires companionship most of all. ${ }^{49}$ Geronimo, warrior leader and medicine man of a band of Chiricahua, claimed that Ussen had not only given him the power of clairvoyance in relation to his enemies but that the creator also protected him from death in battle. ${ }^{50}$

Oral traditions pass on this legacy of holy places, yet the stories these places carry do not always involve spirituality. Many of these stories are literally retellings of journeys home. One such story of this arduous journey home comes from a more recent oral history of the young warrior Massai and his desperate return to the Southwest in $1886 .{ }^{51}$

\footnotetext{
${ }^{44}$ Morris Edward Opler, The Apache Life-Way; The Economic, Social, and Religious Institutions of the Chiricahua Indians (Chicago: University of Chicago Press, 1941), 10.

${ }^{45}$ Stockel, “Rocks, Waters, and Earth,” 21-22.

${ }^{46}$ Basehart, Apache Indians XII, 82.

${ }^{47}$ Ibid., 63-82.

${ }^{48}$ D.C. Cole, The Chiricahua Apache, 1846-1876: From War to Reservation (Albuquerque: University of New Mexico Press, 1988), 13-16.

${ }^{49}$ Ibid, 15-16.

${ }^{50}$ Clemens, Imagining Geronimo140-141.

${ }^{51}$ Sherry Robinson, "Massai and Zanagoliche: An Apache Abduction Turned Enduring Love Story," Wild West 25, no. 4
} 
Though Cochise died during a brief respite in the long Apaches Wars, the insurgency against white incursion into Apache homelands continued under the leader Geronimo and his band of warriors, including young Massai. Massai and many of his brethren, after the surrender of Geronimo in 1886, were transferred by train to their exile in Florida at Fort Marion as prisoners of war. In stifling conditions and with the windows nailed shut with boards, Massai likely pried off one of the roof vents in order to make his escape. As the train neared St. Louis, Missouri, Massai leaped from the car, surviving his fall and eventually making his way back to his sacred homelands in Western New Mexico. ${ }^{52}$

While stories of homecomings feature prominently in Apache oral histories, stories of grief and historical trauma also tie into the Apache sense of place. Two locations in particular, Janos in Chihuahua, Mexico, and Bacoachi in Sonora, Mexico, lurk within Apache collective memory as spaces of forced enclosure. While Spanish missionaries detained Apaches at their Janos mission by force, the Spanish government later confined the Chiricahua to Bacoachi as part of a peace settlement. Many Apaches had sickened and died in these enclosed spaces, leaving a legacy of death, and these stories remain a critical aspect of the Chiricahua spiritual landscape. Apaches view these locales of trauma as sacred to their people, owing to their historical importance. Here, after a life of terror and violence, many Apaches journeyed into the spiritual world through death. ${ }^{53}$

\section{Exile Trauma: A Spiritual Amputation}

The Mescalero Apache removal to Bosque Redondo in Eastern New Mexico in the 1860s, and the Chiricahua Apache removal to Florida and beyond in the 1880s, created an experience akin to a cultural and spiritual amputation. Though they could find ways to heal from this separation through ritual and community, the scars of their removal from their sacred geography would linger. Keith Basso, an anthropologist of place and space in the Apache world, described this loss when discussing homeland attachment and separation in his work with the Western Apaches. He argues that depriving people of their geographic attachments creates a metaphysical dislocation, felt intimately as a threat to the identity. Additionally, he states that, "Places, we realize, are as much a part of us as we are a part of them, and senses of place- yours, mine and everyone else'spartake complexly of both." ${ }^{54}$

The spiritual amputation of exile created cultural phantom pains within the Apache people. As the Long Walk of the Mescaleros progressed and as the train of Chiricahuas moved further away from Apacheria, the feeling would continually remind the Apaches of the lost limb, their heart and homeland that disappeared and simultaneously lingered behind them.

Within these shattered groups, Apache warriors in particular found themselves emasculated by this rift from place. In one way they chose what they hoped would be the immediate safety of their families through a negotiated surrender. In exchange for this peace through removal and cessation of warfare, the warriors of the Mescalero Apaches and later the Chiricahua faced a new life removed from their own relationships with the landscape and it resources. One Chiricahua man, Carl Mangas, the son of famed leader Mangas Coloradas, declared that he could not even care for his family and became inconsolable. As the prison train moved from Holbrook, Arizona, to Florida with his captured family and band on board, he jumped from a train window in an attempted suicide..$^{55}$

Apache women also faced great challenges in their removal from Apacheria. These women played an integral part in the family unit as both a caregiver and resource gatherer. More importantly, women also possessed a sacred connection to the earth around them, uniting their families and band to the land through ritual, ceremonies, and spiritual power. Just as the principle

(2012), 22

\footnotetext{
${ }^{52}$ Joseph C. Jastrzembski, “Treacherous Towns in Mexico: Chiricahua Apache Personal Narratives of Horror.” Western Folklore 54, no. 3 (1995), 169-196.

${ }^{53}$ Stockel, "Rocks, Waters, and Earth," 23.

${ }^{54}$ Keith Basso, Wisdom Sits in Places: Landscape and Language among the Western Apache (Albuquerque: University of New Mexico Press, 1996), xiii-xiv.

${ }^{55}$ Boyer and Gayton, Apache Mothers and Daughters, 101.
} 
Apache deity White Painted Woman had brought men, her children, into being when the world was still new, women represented the ultimate spiritual force: creation. ${ }^{56}$

The puberty ceremony, rooted in celebration of menarche and a young lady's rise to possible motherhood, remains one of the Apache's oldest and most important rituals. As economic leaders, women also provided the majority of daily food, with gathering traditions taught to daughters at a young age. Women directed the migration patterns across the region during particular seasons according to the growth patterns of traditional wild crops. These women did not merely take from the earth as needed. Instead they engaged in this economic practice in a way that intermingled with the spiritual. ${ }^{57}$ When gathering these necessities from the earth, Apache women always prayed in thanks of the power that each food contained, as they did for all plant and animal resources that existed within their territory. ${ }^{58}$

Apache children of the 1880s occupied a much more chaotic world than their grandparents. In the maternal oral traditions of the Gayton family, young Beshad-e grew up under the shadow of her grandfather Victorio's wars. As a child she learned to carry a knife hidden somewhere on her body at all times. More importantly, she learned to incorporate aspects of the environment into her daily existence as a means of flight. ${ }^{59}$ Apaches taught their young children to carry pouches of dried foodstuffs constantly, in case of a sudden attack and a need for rapid escape, so that the children would be fed until they found their way back to the band. Similarly, Apaches hid preserved foods within the caches of canyon walls, committing their location to memory for those days of terror, fleeing and hiding from either Mexicans or Americans. Having already faced violence and racial persecution, the suffering of removal and exile simply added another layer to the complex ethnotrauma that the Apaches lived with each day as a people. ${ }^{60}$

Edward Said profoundly expressed the agony of removal in his essay "Reflections on Exile." He proclaims exile as "the unhealable rift forced between a human being and a native place, between the self and its true home: its essential sadness can never be surmounted." ${ }^{11}$ Said seeks to dispel the romanticism of exile so commonly featured in literature, arguing that this process remains a real, historical trauma for those living through it. Exile does not exist as its own entity or as a process in which to take part. Rather, one group of people imposes this experience upon another group. ${ }^{62}$ Exile for the Chiricahua and Mescalero Apaches, with such innate connections both economically, culturally, and spiritually to their home space, would prove doubly traumatic. As prisoners of war and transported far from home, this exile imposed a new present. Apache life was constantly haunted by echoes of places within their past, putting both groups into a limbo of extreme duress and heartache. Scents, sounds, and tactile experiences grew into bittersweet connections to their ever-present grief as the Apaches began their adaptation to a new landscape far away from home.

Amanda Wise argues in "Embodying Exile," as she explores trauma and collective identities among East Timorese refugees in Australia, that this community even in exile remains permeated by the memory of previous violence. ${ }^{63}$ Wise examines how East Timorese refugees, in the wake of twentieth century Indonesian occupation of their homeland, became a group bound by the trauma of exile. Ghosts of places of violence and group members lost plagued the Apaches as well. While living in Apacheria, these Indigenous groups placated the haunted lands through ceremonies, connecting them back to the now cleansed earth. As many loved ones died far from home, Apache peoples feared ghost sickness, a physical and emotional condition brought on by the death of a family member and normally avoided through meticulous burial practices tied in

\footnotetext{
${ }^{56}$ Trudy Griffin-Pierce, Chiricahua Apache Enduring Power (Tuscaloosa: University of Alabama Press, 2011), 32-33.

${ }^{57}$ Ibid., 33-35.

${ }^{58}$ Boyer and Gayton, Apache Mothers and Daughters, $19 .$.

${ }^{59}$ Ibid., 94.

${ }^{60}$ Ibid., 94 .

${ }^{61}$ Edward Said, Reflections on Exile and other Essays (Cambridge: Harvard University Press, 2000), 173.

${ }^{62}$ Ibid., 173-186.

${ }^{63}$ Amanda Wise, "Embodying Exile: Trauma and Collective Identities among East Timorese Refugees in Australia," Social Analysis 48, no. 3 (2004), 31.
} 
with the Apache landscape. ${ }^{64}$ As both the Mescalero and the Chiricahua peoples moved eastward, disconnection from their home and themselves grew exponentially greater. Wise further notes how trace memories of places and homes in the past could even impact young children born in exile. For Wise, trauma exists in multiple forms, whether through direct violence or a narrative legacy of violence, which becomes an integrated part of the community in Diaspora. ${ }^{65}$ Children born into these exiled Native groups in western New Mexico territory, Florida, and later in Alabama and Oklahoma arrived through their birth into this ongoing trauma. Stories and songs passed down from their parents and the oral histories of creation and spirit created a metaphorical ghost among the Apache children, one that many of these children, born into captivity, could chase but never capture.

Further complicating this exile trauma, Wise notes that traumatized communities living in diaspora are barraged with whatever role the public that surround them creates in their regard. ${ }^{66}$ Similarly, Apaches found themselves forced to carry a burdensome identity for the public, eternally defined and incarcerated for their supposed "crimes" based on their group ethnic guilt. Thus the racial persecution that they faced previously through violence continued as a narrative thread in exile and within the layers of larger ethnotrauma. Though this persecution had lost most of its violent elements, it then took on a more subtle and sinister nature, attempting to control the very identity of the Apache people.

In the case of both Apache groups, this enforced disconnect from earth's creations made their survival exceedingly difficult, hindering their ability to adapt while enclosed and imprisoned. Yet the Apache story does not remain hopeless. As the Mescalero symbolically reaffirmed their own agency as a people through their emboldened escape from Bosque Redondo, the Chiricahua people continued the critical rituals of puberty ceremonies and spiritual dances during their time in captivity in Florida and beyond until their ultimate release from prisoner status in 1913. While some of the Chiricahua Apaches would remain in Fort Sill, Oklahoma, their final removal location as prisoners of war, other members of the Chiricahua tribe would eventually return to the Southwest, sharing a home with their cousin tribe, the Mescalero Apaches, in southern New Mexico. ${ }^{67}$

\section{Conclusion}

The story of young Francesca's experience with violence and captivity is one of many Apache stories which illustrates concept of ethnotrauma as lived through by many other Nativepeoples of the American Southwest. For Mescalero and Chirichua peoples, their experience with ethnotrauma would possess unique, Indigenous characteristics as these two groups faced the traumatic implications of collective exile from their sacred homeland. In 1886 Francesca found herself a captive yet again, but not as a slave in a foreign land. This time the United States military shipped her and her family along with other members of Geronimo's band to Fort Marion near Saint Augustine as prisoners of war. Though she never fully regained the use of her hands and often hid the scars from her fight with the jaguar on her face with a cloth, she became a revered medicine woman for the group while in captivity. Other Apaches remembered her ceremonial singing during the Dance of the Mountain Gods, even while hidden behind a veil to cover what she viewed as an ugly mark on her beauty. During the Chiricahua imprisonment in Fort Marion, and with women and children dying around her from disease in a harsh, foreign climate, Francesca sang the songs of her people that connected them with a land which seemed so infinitely far away ${ }^{68}$ To the public who periodically ventured to see the Apaches imprisoned as local curiosities, these sounds likely seemed foreign and could have been interpreted as merely an expression of a Native woman's

\footnotetext{
${ }^{64}$ Morris E. Opler and William E. Bittle,“The Death Practices and Eschatology of the Kiowa Apache," Southwestern Journal of Anthropology 7, no. 4 (1961), 383-94.

${ }^{65}$ Wise, "Embodying Exile," 31.

${ }^{66}$ Ibid., 36.

${ }^{67}$ John Anthony Turcheneske, The Chiricahua Apache Prisoners of War: Fort Sill, 1894-1914 (Boulder: University Press of Colorado, 1997), 155-166.

${ }^{68}$ John Albert Sleicher, ed. “Huera: Instigator of the Apache Outbreak” Leslie's Vol. 61-63, New York: F. Leslie, (July 31, 1886) 380 .
} 
longing for home. To one more familiar with Apache culture, however, this keening would seem almost like the wailing songs performed in the hours after a beloved's death. With no peaks or canyon cliffs in sight, perhaps the Apaches mourned not only for those loved ones they had lost in their struggles but also for a loss of spirit, as they strained to hear the distant drumming of the Mountain Gods.

\section{Bibliography}

Ahmed, Ameena T., Selina A. Mohammed, and David R. Williams, "Racial Discrimination and Health: Pathways and Evidence." Indian Journal of Medical Research 126, no. 4 (2007): 318.

Alvarez, Alex. Native America and the Question of Genocide. Lanham: Rowman \& Littlefield, 2014.

Ball, Eve. “Big Mouth." n.p. Eve Ball Papers, Manuscript Collection 3096, L. Tom Perry Collection, 20th and 21st century Western and Mormon Americana, Harold B. Lee Library, Provo, United States of America. Box 3, Folder 22.

---.Indeh: An Apache Odyssey. Norman: University of Oklahoma Press, 1980.

Ball, Martin. "Sacred Mountains, Religious Paradigms, and Identity Among the Mescalero Apaches." Worldviews: Global Religions, Culture, and Ecology 4, no. 3 (2000): 264-282. http://dx.doi.org/10.1163/156853500507852

Basehart, Harry W. Apache Indians XII; Mescalero Apache Subsistence Patterns and Socio-Political Organization. New York: Garland Publishing Inc., 1974.

Basso, Keith. Wisdom Sits in Places: Landscape and Language among the Western Apache. Albuquerque: University of New Mexico Press, 1996.

Boyer, Ruth McDonald and Narcissus Duffy Gayton. Apache Mothers and Daughters: Four Generations of a Family. Norman: University of Oklahoma Press, 1992.

Brooks, James F. Captives and Cousins: Slavery, Kinship, and Community in the Southwest Borderland. Durham: University of North Carolina Press, 2011.

Caruth, Cathy, ed. Trauma: Explorations in Memory. Baltimore: John Hopkins Press, 1995.

Clemens, William M. Imagining Geronimo: An Apache Icon in Popular Culture. Albuquerque: University of New Mexico Press, 2013.

Cole, D.C. The Chiricahua Apache, 1846-1876: From War to Reservation. Albuquerque: University of New Mexico Press, 1988.

Cremony. John C. Life Among the Apaches. San Francisco: A. Roman \& Company, 1868.

Cruz-Pierre, Azucena, Donald A. Landes, and Contributors, Exploring the Work of Edward S. Casey: Giving Voice to Place, Memory, and Imagination. London: Bloomsbury, 2013.

Debo, Angie. A History of the Indians of the United States. Norman: University of Oklahoma Press, 1970.

Farrer, Claire R. Living Life's Circle: Mescalero Apache Cosmovision. Albuquerque: University of New Mexico Press, 1994.

Griffin-Pierce, Trudy. Chiricahua Apache Enduring Power. Tuscaloosa: University of Alabama Press, 2011.

Harvey, Harvey. "Landscape and Commerce: Creating Contexts for the Exercise of Power." In Contested Landscapes: Movement, Exile, and Place, edited by Barbara Bender and Margot Winer, 197-210. Oxford: Berg Publishers, 2001.

Jastrzembski, Joseph C. "Treacherous Towns in Mexico: Chiricahua Apache Personal Narratives of Horror." Western Folklore 54, no. 3 (1995): 169-196. http://dx.doi.org/10.2307/1500346

LaCapra, Dominick. History and Memory after Auschwit. Ithaca: Cornell University Press, 1998.

LaCapra, Dominick. Writing History, Writing Trauma. Baltimore: John Hopkins University Press, 2001.

Lahti, Janne. "Silver Screen Savages: Images of Apaches in Motion Pictures." Journal of Arizona History 55, no. 1 (2013): 51-79.

Lemkin, Raphael. Axis Rule in Occupied Europe: Laws of Occupation - Analysis of Government - Proposals for Redress. Washington, D.C.: Carnegie Endowment for International Peace, 1944.

Keleher, William A. Turmoil in New Mexico: 1846-1848. Albuquerque: University of New Mexico Press, 1952. 
Madley, Benjamin. "Reexamining the American Genocide Debate: Meaning, Historiography, and New Methods," The American Historical Review 120, no. 1 (2015): 98-139. http://dx.doi. org/10.1093/ahr/120.1.98

Opler, Morris Edward. The Apache Life-Way; The Economic, Social, and Religious Institutions of the Chiricahua Indians. Chicago: University of Chicago Press, 1941.

Opler, Morris Edward and William E. Bittle, "The Death Practices and Eschatology of the Kiowa Apache," Southwestern Journal of Anthropology 7, no. 4 (1961): 383-94. http://dx.doi. org/10.1086/soutjanth.17.4.3628949

Robinson, Sherry. Apache Voices: Their Stories of Survival as Told to Eve Ball. Albuquerque: University of New Mexico Press, 2000.

---."Massai and Zanagoliche: An Apache Abduction Turned Enduring Love Story," Wild West 25, no. 4 (2012): 22.

Rothberg, Michael. Multidirectional Memory: Remembering the Holocaust in the Age of Decolonization. Stanford: Stanford University Press, 2009.

Said, Edward. Reflections on Exile and other Essays. Cambridge: Harvard University Press, 2000.

Leslie, Frank. "Huera: Instigator of the Apache Outbreak." In Leslie's Vol. 61-63, edited by John Albert Sleicher, 369-384. New York: F. Leslie, July 31, 1886.

Sonnichsen, C.L. The Mescalero Apaches. Norman: University of Oklahoma Press, 1958.

Stockel, H. Henrietta. "Rocks, Waters, and Earth: Chiricahua Apache Spiritual Geography." Journal of the West 46, no. 4 (2007): 12.

Stockel, H. Henrietta. Salvation through Slavery: Chiricahua Apaches and Priests on the Spanish Colonial Frontier. Albuquerque: University of New Mexico Press, 2008.

Sweeney, Edwin R. Cochise: Chiricahua Apache Chief. Norman: University of Oklahoma, 1991.

---.Cochise: Firsthand Accounts of the Chiricahua Apache Chief. Norman:University of Oklahoma, 2014.

---. From Cochise to Geronimo: The Chiricahua Apaches, 1874-1886. Norman: University of Oklahoma Press, 2010.

Thrapp, Daniel L. The Conquest of Apacheria. Norman: University of Oklahoma Press, 1967.

Turcheneske, John Anthony. The Chiricahua Apache Prisoners of War: Fort Sill, 1894-1914. Boulder: University Press of Colorado, 1997.

Wise,Amanda. "Embodying Exile:Traumaand CollectiveIdentitiesamongEastTimorese Refugeesin Australia." Social Analysis 48, no. 3 (2004): 31. http://dx.doi.org/10.3167/015597704782352456

Wolfe, Patrick. "Settler Colonialism and the Elimination of the Native." Journal of Genocide Research 8, no. 4 (2006) 387-409. http://dx.doi.org/10.1080/14623520601056240 